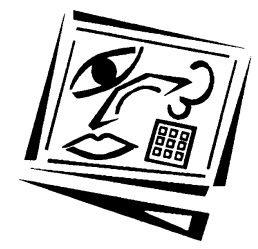

\title{
Real thinking with virtual hats: A role-playing activity for pre-service teachers in Second Life
}

\author{
Sue Gregory and Yvonne Masters \\ University of New England
}

\begin{abstract}
Role-plays in a virtual world hold tremendous potential for higher education because they allow synchronous, immersive participation by students located across the globe. They also have the added advantage of allowing students to adopt roles and carry out tasks that are not possible in the real world. In this article, a project that involved preservice teachers carrying out role-plays based on de Bono's Six Thinking Hats framework is presented. A pilot study was carried out over two years with on-campus students, who performed the role-plays both in a real-life, physical setting and within the virtual world of Second Life. The activity has since been extended to off-campus students exclusively using Second Life. The authors report selected quantitative and qualitative survey data from the pilot study that provide insight into students' perceptions of this style of learning, and discuss the challenges that were encountered and how they were overcome. The future of virtual world-based role-playing as a strategy for teaching and learning is discussed, with a focus on its application to distance education contexts.
\end{abstract}

\section{Introduction}

The study described in this article was conducted at the University of New England (UNE), with an overall aim of investigating ways in which traditional teaching of preservice teachers can be enhanced through the use of virtual worlds, and the degree of engagement experienced by students while undertaking virtual world activities. UNE is predominantly a distance education provider, with more than $80 \%$ of its students choosing to study in off-campus mode (UNE, 2011). For off-campus primary education students who, from 2010, have been required to study the same units as their oncampus counterparts, engaging and effective online experiences needed to be developed and delivered in different ways. In 2009, we researched, developed and trialled a role-play workshop for on-campus pre-service teachers in the virtual world of Second Life. This pilot enabled us to refine the teaching and learning experience prior to offering the same workshops to off-campus students via this medium. Since 2010, off-campus students have been able to undertake similar experiences to on-campus students through what is perceived as 'face-to-face' learning in a virtual world (Gregory, 2011).

The role-play developed was based on Edward de Bono's (1985) Six Thinking Hats framework. The metaphor of the Six Thinking Hats demonstrates different types of thinking, and is now widely used as a teaching and learning strategy in schools. It is used to encourage students to think about their own thinking (metacognition) and to 'mentally shift gears' to consider different perspectives on a topic (Gregory \& Masters, 2010). This strategy, introduced to primary education students at UNE as an integral 
section of a teaching and learning unit in the first year of their degree, is used as one teaching and learning strategy within pre-service teacher training, and can later be used by these student teachers in their own teaching practice for classroom management and discussions. De Bono's framework is taught most effectively through role-play in workshops, as this allows the pre-service teachers to put it into context. A major challenge for us was to develop a means to provide this enhanced experience to pre-service teachers studying in off-campus mode, students for whom there are no face-to-face workshops and also for whom all teaching materials are delivered online.

During the pilot with on-campus students, comparisons were made between real-life and virtual world-based workshops focussing on student perceptions of their learning and engagement, using surveys, observations and recordings of online dialogue. The analysis of data from this pilot assisted in further refinement of the activities in real life and the virtual world. Subsequent to the pilot, the role-play was undertaken with offcampus students.

In this article, we describe the development of the pilot, discuss the rationale for using the Six Thinking Hats framework, and clarify methodological issues such as the controls that were put in place between the real-life and virtual world workshops. We then progress to a discussion of the challenges that were encountered, the results, the refinements that were made and the success of the implementation with off-campus students. We conclude the article with an outline of our future plans for virtual world classrooms, particularly in the area of distance education.

\section{Background and literature review}

\section{Virtual worlds for learning and teaching at UNE}

With a history as a major provider of distance education in Australia, UNE has undergone considerable change in recent years in an effort to establish itself at the forefront of online and flexible learning. Over the past decade, the University has provided all students with study materials via the Internet. However, for on-campus students, face-to-face lectures and workshops are still the principal means of imparting knowledge. Off-campus students are not able to attend these face-to-face sessions, and so a range of delivery methods were used to cater to these students in the past, including paper-based materials and CDs. Currently, almost all delivery to UNE's offcampus students occurs through the University's learning management system (LMS), with content presented in the form of static hypertext markup language (HTML) web pages and portable document format (PDF) files, and with communication facilitated asynchronously through discussion boards, wikis and blogs, plus some limited use of text-based synchronous chat.

To more deeply engage students studying at a distance, a virtual world such as Second Life can be used to hold online classes synchronously (at the same time, like in a chat room) while continuing to leverage the benefits of asynchronous (i.e. at different times, as in a discussion forum) modes of communication both within and outside of the virtual world. Virtual worlds are multi-user, interactive, computer-simulated environments created for users to inhabit and interact via avatars (Gregory \& Tynan, 2009) - graphical representations of themselves that they can personalise (Gregory \& Smith, 2010) for use in the virtual world. Preliminary research at UNE by the first author in 2008 demonstrated that students appreciate this environment because they feel as if they are really 'there' with their classmates and lecturer; for these students, the 
experience is, in many ways, akin to a face-to-face encounter (Gregory \& Tynan, 2009). This mode of learning is far more engaging and meaningful for students than passively receiving their materials online via the LMS.

Virtual worlds provide the capacity to simulate aspects of the real or physical world, providing a low cost space that can supplement and/or substitute real-world activities (Gregory, 2009). The study described in this article was conducted at UNE to investigate whether traditional teaching of pre-service teachers could be effectively approximated, replicated or possibly even enhanced in a virtual world through a roleplaying activity, firstly in real life and then in Second Life.

\section{Second Life and role-plays in higher education}

UNE is among the many higher education institutions across Australia and New Zealand that have been exploring innovative ways in which virtual worlds can be used to support and enhance teaching and learning (see Dalgarno, Lee, Carlson, Gregory \& Tynan, 2011; Gregory et al., 2010; B. Gregory et al., 2011; Lee, Dalgarno, Gregory, Carlson \& Tynan, 2011). Second Life is by far the most commonly used virtual-world platform at these institutions (Dalgarno et al., 2011), as appears to be the case with most institutions on a worldwide scale (Liu, Kalk, Kinney \& Orr, 2012). It was for this reason, coupled with the fact that one of us (Gregory, the first author of the present article) has extensive experience using it, that Second Life was chosen as the platform for the present study.

Second Life is "an immersive and interactive virtual world with all of the content, including objects, locations, and people, being user-generated" (Liu et al., 2012, p. 164). It was opened to the public by its proprietors, Linden Lab, in 2003. In 2010, Linden Lab claimed that there were approximately 750 institutions across the globe operating their own islands in Second Life (this figure did not take into account institutions that owned smaller parcels of virtual land). At any one time, more than 40,000 people are logged in and using Second Life (Linden Research, 2009).

Second Life was also selected because it provided a variety of aspects that the research project required, such as text-based anonymity, the availability of easy-to-use synchronous communication mechanisms, as well as visual representation of avatars that can be readily customised, which has also been highlighted as a benefit by GreenHamann, Eichorn and Sherblom (2011) in a study where they used Second Life to explore social groups. Second Life also gives educators the ability to mimic real-life situations and activities, using the tools provided by the platform to build games and simulations (including role-plays), as well as to promote opportunities for students to engage in playful and productive identity construction, communication and interaction (Backe, 2011; Mayrath, Sanchez, Traphagan, Heikes \& Trivedi, 2007).

According to Inman, Wright and Hartman (2010), "Second Life has the capacity to facilitate role-play activities that are equally effective as role-play activities in the real world" (p. 53). One of the goals of the present study was to test this assertion. In support of their claim, Inman et al. review three studies involving role-play in Second Life, namely those conducted by Gao, Noh and Koehler (2008), Mayrath et al. (2007), and Rappa, Yip and Baey (2009). Gao et al. (2008) used physical and virtual role-plays to compare student performances in the concepts of motivation; Mayrath et al. (2007) used role-play in Second Life to capitalise on existing knowledge of the software role- 
playing leadership through role models; Rappa et al. (2009) had students role-play as teenagers through to adults for diet and difficulties relating to euthanasia.

In the area of teacher education, the TeachLivE team from the University of Central Florida (http: / / mclserver.eecs.ucf.edu/teachlive/) has been facilitating role-plays in which their students teach simulated avatars in a virtual world. Part of their effort has been centred around looking at teaching in mixed-reality environments (i.e. environments that combine elements of the real and virtual worlds) in the form of the TeachME project (Andreasen \& Haciomeroglu, 2009). TeachLiVE and TeachME build on a long tradition of research on role-play in text-based and $2 \mathrm{D}$ online learning environments (see, for example, Beach \& Doerr-Stevens, 2009; Lee, Eustace, Fellows, Bytheway \& Irving, 2005; Phillips, 2005; Slator \& Chaput, 1996), and their outcomes suggest that virtual world-based role-plays have the potential to assist pre-service teachers in developing sound classroom and behaviour management strategies.

We (the authors of the present article) are also involved in an ongoing project that is in many ways similar to TeachLivE and TeachME. As part of the VirtualPREX project (see Gregory, Dalgarno, Campbell, Reiners, Knox \& Masters, 2011), we have created a number of role-play scenarios that student teachers can undertake within a virtual school classroom environment in Second Life, either collaboratively with their peers or independently in their own time. To support such independent learning, non-player characters or 'bots' representing schoolchildren are being implemented that the student teachers will be able to interact with, thereby allowing them to carry out the role-plays without the need for other students or lecturers to be simultaneously logged in. The bots are being programmed with automated responses to a variety of text and other stimuli, so that the student teachers will be able to 'teach' lessons to the bots and experience simulated reactions from them, opening up possibilities for experimentation with different instructional strategies and behaviour management techniques within the virtual world. Preliminary feedback from the student teachers who have been involved in the VirtualPREX project thus far indicates they appreciate the ability to practise teaching when real classrooms and students are not available, and this is especially the case with off-campus students. They value the opportunities afforded by the environment to apply and refine their techniques in a risk-free environment in preparation for their real-life teaching professional experience (S. Gregory et al., 2011).

\section{Learner engagement in virtual role-play}

Students' motivation to learn relates to their beliefs about their academic competence, their intelligence, their values pertaining to the different subject matter and their individual goals toward learning (Roeser, Strobel \& Quihuis, 2002). When a student has his/her beliefs, values and goals aligned, he/she becomes more engaged in his/her learning. Engagement refers to the "time, energy and resources students devote to activities designed to enhance learning" (Krause, 2005, p. 3). It is multidimensional, and can be divided into three categories: affective, behavioural and cognitive. It is a combination of an individual's feelings (affective), observable actions or performance (behavioural), and his/her perceptions and beliefs (cognitive) (Jimerson, Campos \& Greif, 2003; Russell, Ainley \& Frydenberg, 2005).

$\mathrm{Hu}$ and Kuht (2002, p. 571) claim that "student engagement is a function of the interaction of the student and institutional characteristics", which can be measured through teacher and student observation and reporting (Reading, 2008). Greene and 
Miller (1996) reported that achievement in the classroom is determined by a student's perceived ability and learning goals, which influence meaningful cognitive engagement. If someone is engaged, they "have a sense of energetic and effective connection with the activities they are undertaking" (Schaufeli, Bakker \& Salanova, 2006, p. 702).

In the present project, it was hoped that the role-playing activity would give rise to "student engagement in authentic learning... designed to achieve desired learning outcomes", and that through the activity, students would develop "skills for seeking out the required knowledge as the changing situation demanded" (Reaburn, Muldoon \& Bookallil, 2009, p. 821). Engagement in the context of the present study was measured through observation, surveys and online dialogue recordings using the three types of engagement outlined above - that is, affective, behavioural and cognitive. The research questions framing the study were designed around these three areas:

1. Can a learning activity based on role-play in the real world be replicated effectively in a virtual world?

2. How engaged are students when undertaking a real-life role-play as compared to an equivalent virtual world-based role-play?

3. Can de Bono's Six Thinking Hats be taught to off-campus students through engagement in their learning in a virtual world?

\section{Research design}

\section{Project aims and methodology}

The main objective of this research was to explore whether a virtual world is a feasible educational tool that can be incorporated easily into a teacher educator's repertoire of resources, particularly where off-campus students are involved. Because we were initially unsure of the amount of assistance that students might require to become familiar enough with Second Life to successfully partake in the activity, a decision was made to trial the activity with students who were based on-campus, where difficulties could be monitored, and troubleshooting and other forms of technical support were more readily available. An added benefit of initially restricting the study to on-campus students was that the activity could be duplicated in real life and Second Life to provide a basis for comparison in terms of students' perceptions of their learning and engagement.

The project employed action research methodology as described by Kemmis and McTaggart (1988), and consisted of two cycles or stages. The pilot study with oncampus students represents the first stage, which forms the primary focus of this article. The work carried out in this stage followed the four action research phases of planning, implementation, observation and reflection. The planning was done in early to mid-2009, when the researchers defined the research questions, determined the data collection methods, and designed the tools and procedures for the study. Implementation occurred in late 2009, following which observations were made and documented and feedback received from the students; these data were analysed and reflected upon to implement a refined workshop in the following year. The action research cycle continued in 2010 with the second stage of the project, during which further planning, implementation, observation and reflection were undertaken to 
enable the role-play workshops to be offered to off-campus cohorts. The results of the second stage will be reported in other publications.

\section{Participants and context}

The students who participated in the study were pre-service teachers enrolled in a teaching and learning unit as part their first year in UNE's four-year Bachelor of Education (Primary) program. They had no prior experience using Second Life. The real-life version of the Six Thinking Hats role-playing activity was intended to address four of the unit's six learning objectives, namely the ability to:

1. Analyse how key concepts of learning theory, including child development (social and emotional), relate to quality teaching;

2. Plan for quality teaching and learning using a range of whole-class and smallgroup strategies;

3. Facilitate a discussion (online or face-to-face) to identify and explore key teaching and learning concepts;

4. Self- and peer-assess contributions to team activities.

In addition to addressing the above objectives, the virtual world-based version of the activity related to a fifth objective of the unit, which called for students to be able to:

5. Demonstrate a capacity to work collaboratively and effectively in an ICT environment.

In all, 96 on-campus students participated in both the real-life and virtual world-based workshops and completed the surveys over the two years of the pilot study (80 in 2009, 16 in 2010). A total of 22 of the participants were male and 74 were female, as shown in Table 1. Students who did not participate in both of the workshops and those who did not complete the surveys were excluded, as they would not have allowed for valid comparisons to be made. It should be noted that in the first year, the students were divided into four workshop groups of up to 24 students per group to participate in the activity; in the second year the authors only had access to one group of 28 students, of whom 16 participated in both workshops and completed the surveys.

Table 1: Pilot study sample

\begin{tabular}{|l|c|c|c|c|c|c|}
\hline \multirow{2}{*}{} & \multicolumn{2}{|c|}{2009} & \multicolumn{2}{c|}{2010} & \multicolumn{2}{c|}{ Total } \\
\cline { 2 - 7 } & $n$ & $\%$ & $n$ & $\%$ & $n$ & $\%$ \\
\hline Male & 16 & 20.0 & 6 & 37.5 & 22 & 22.9 \\
\hline Female & 64 & 80.0 & 10 & 62.5 & 74 & 77.1 \\
\hline Total & 80 & 100.0 & 16 & 100.0 & 96 & 100.0 \\
\hline
\end{tabular}

\section{The virtual environment}

To assist the research, a 3D virtual classroom and playground were created in Second Life, based loosely around what a student teacher can typically expect to encounter in an actual primary school. The classroom (see Figure 1) includes student and teacher desks and chairs, a whiteboard, a chalkboard, student work displayed around the room, interactive books with pages that can be read and turned, as well as games that call for collaboration with others and/or testing of one's own skills. In the playground (Figure 2) are a variety of 'working', interactive play equipment, among which are bikes, skateboards, swings, climbing frames, seesaws, a sandpit, a limbo pole, and balls 
able to be bounced, kicked and thrown. Six different coloured hats that avatars are able to pick up, put on and take off were also created in the environment for the purpose of the role-playing activity.

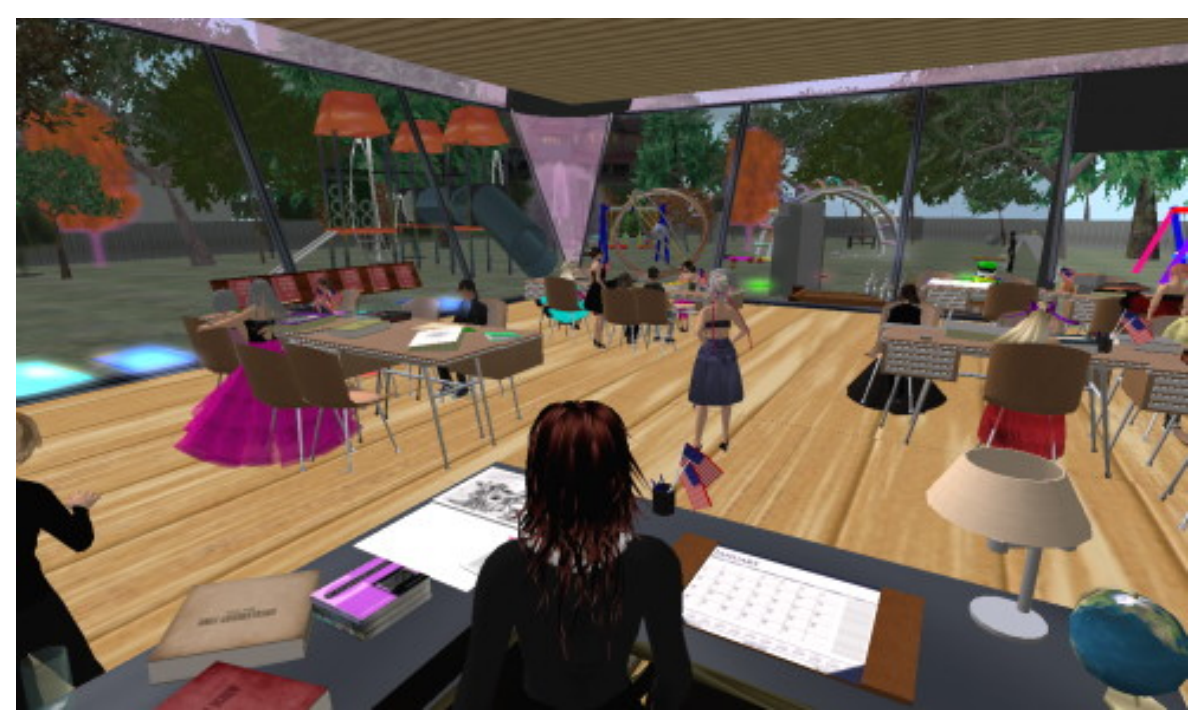

Figure 1: Virtual school classroom

The virtual environment was developed with a range of resources for teacher educators to use with their students as if they were working at a real school. While Second Life allows for the creation of fantasy environments, the classroom and playground were based on the physical structure of those seen in real life so as to maximise the likelihood of transfer of learning occurring between the real and virtual worlds. The virtual classroom is also frequently used for practice teaching, for instance as part of the VirtualPREX project (S. Gregory et al., 2011).

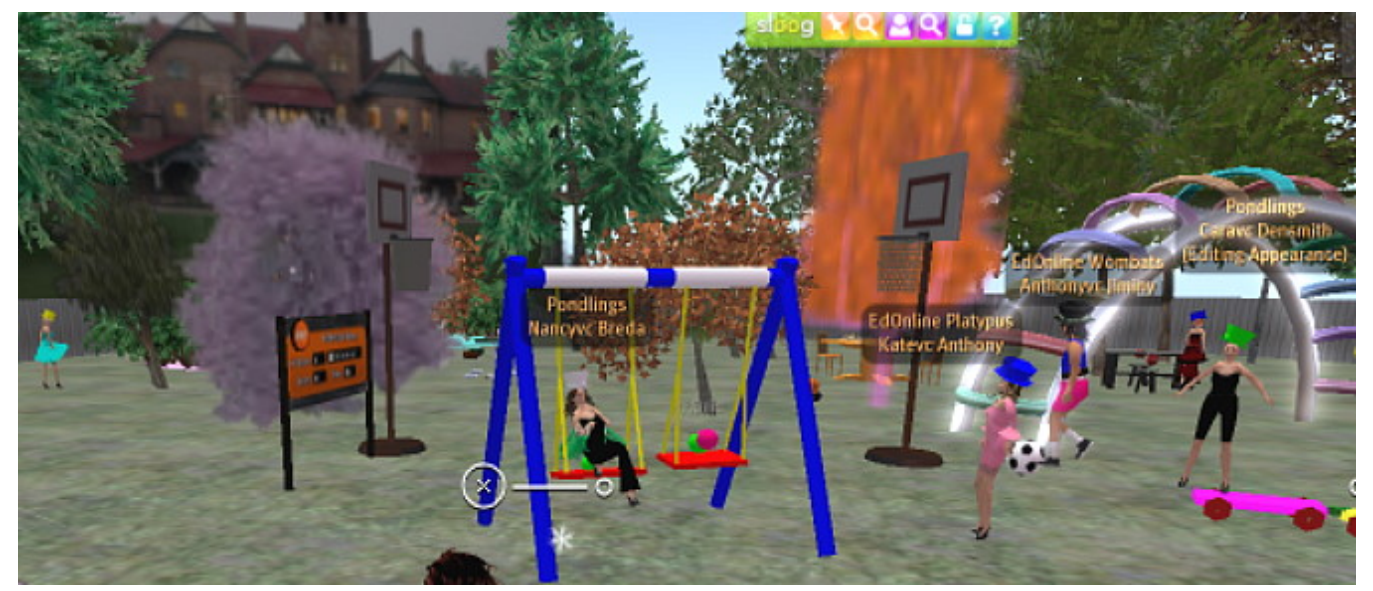

Figure 2: Virtual school playground 
An evaluation of student perceptions of the virtual school environment and its suitability as a site for learning and teaching has been conducted, and is reported in Gregory (2011).

\section{Orientation and learning tasks}

Prior to any work being done within the virtual classroom, University ethics approval was obtained to permit observation of the students in both real life and Second Life, recording of all online conversations, and collection of data from the participants via surveys. The use of multiple methods and sources enabled the gathering of data from several different angles and allowed for triangulation. This article reports selected data from the surveys; the data from the other sources are beyond its scope and will be the focus of other publications.

At the commencement of the study, the students attended an on-campus lecture in which they were given an overview of, and introduction to, the Six Thinking Hats framework. The Six Thinking Hats (de Bono, 1985) is a higher-order thinking scaffold that can be used to encourage students to think in complex and creative ways by assisting them in considering multiple perspectives on a topic. They depict six personalities with different emphases:

- White hat: facts, figures and objective information;

- Red hat: emotions and feelings;

- Black hat: logical, negative thoughts;

- Yellow hat: positive, constructive thoughts;

- Green hat: creativity and new ideas;

- Blue hat: control/ coordination of the other hats and thinking steps.

When used as a lens through which to consider an issue or problem, the Six Hats prompts the user to pause and contemplate various alternatives, instead of coming to a conclusion instantaneously based on narrow, preconceived ideas (de Bono, 1985).

Following the introductory lecture, the students subsequently participated in a twohour, real-life workshop whose purpose was to give them the opportunity to practise working with the Six Thinking Hats framework. During the workshop, they were reminded about the meaning of each hat and were divided into teams of six to engage in role-play and discussion using the framework, with each member taking on a different role based on the colour of the hat they were assigned. The topic of discussion was how the student teachers could use the Six Thinking Hats framework to engage primary school students in their future classrooms. Roles were rotated so that students experienced role-playing a different coloured hat (and therefore had to respond differently), and teams were shuffled. The types of questions the students needed to pose and consider as part of their various hat 'personas' are outlined in the graphic in Figure 3, to which they had access and could refer during the activity.

The use of an activity incorporating de Bono's Six Thinking Hats was considered appropriate for this research for two main reasons. Firstly, the content was considered relatively easy to replicate in Second Life. Secondly, because the students would be required to consider the efficacy of the virtual world classroom and playground from six perspectives, the data were expected to provide well-considered views. 


\section{The Questions to be Asked}

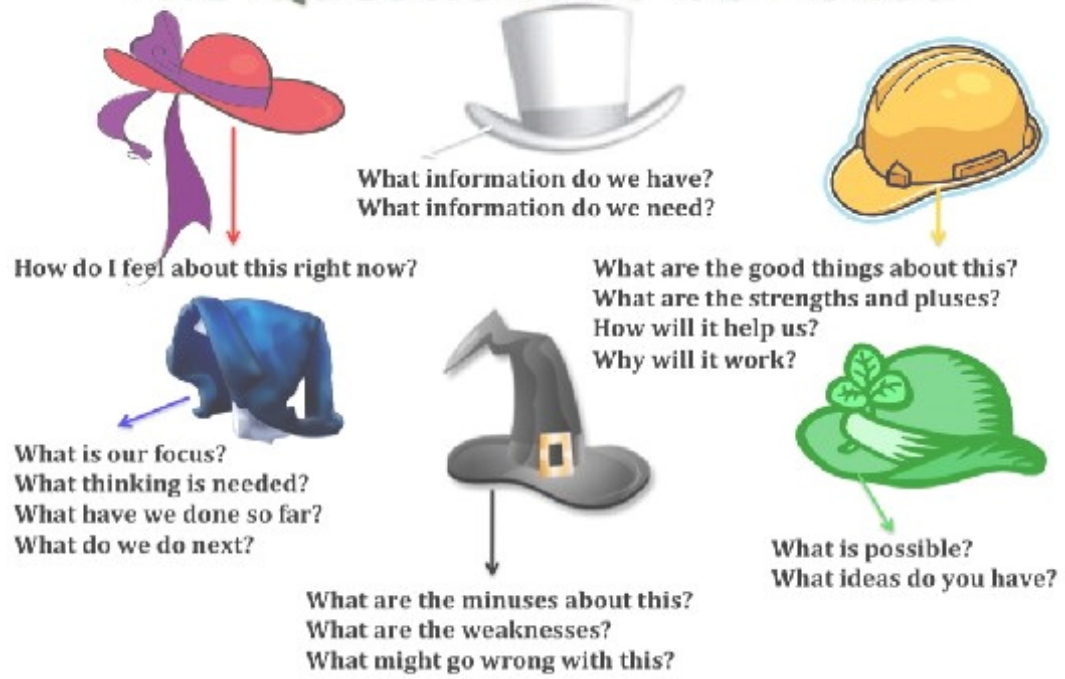

Figure 3: Six Thinking Hats questions

Two weeks after the real-life workshops, the students were prepared for their experience in Second Life through another lecture introducing them to the platform and to the virtual environment that had been created for the activity. Avatars were created for them to use, and they were taught to function within the environment, including how to move about (i.e. walk), communicate (i.e. talk via text chat), use the equipment, sit on chairs at desks, and put the hats on so that they could begin role-playing. They were also shown how to use Second Life's 'group chat' feature so that only members of their own team, as well as the researchers, would be privy to the conversation.

Our avatars (see Figure 4), which are virtual representations of ourselves, were used to teach in the virtual environment. Gregory has been teaching in Second Life since 2008 through her avatar, Jass Easterman, and she has over 20 years of real-life teaching experience. On the other hand, Masters, whose avatar is Tamsyn Lexenstar, is relatively new to teaching in a virtual world, although she has over 30 years of real-life teaching experience. Gregory created a virtual classroom and playground for student use, and her role was primarily observational and to provide troubleshooting if and when required. Masters conducted the real-life and virtual world workshops as part of her teaching responsibilities. To aid Masters' use of the environment, Gregory provided Masters with two orientation sessions and gave a preliminary lecture to Masters' students to teach them how to use Second Life during their workshops.

The virtual world workshops were essentially repeats of the real-world workshops within the Second Life environment, with all actions and speech enacted through avatars, but with one key difference: students were instructed to keep their personal identities secret, and to go solely by the names of their avatars. It was thought that this anonymity would serve to encourage students to speak more freely and openly, without fear of being judged by others. Announcements and other communication intended for all participants were transmitted via text typed in the 'local chat' window, while the intra-team communication was restricted to the respective teams via group 
chat. This method ensured that discussion among team members was not interrupted or influenced by the conversations of other teams. Such segregation of dialogue is difficult to achieve in a real-life situation because when students are located in the same physical space or vicinity, they may hear what those in other groups in close proximity to them are saying, either unintentionally or as a result of deliberate eavesdropping.

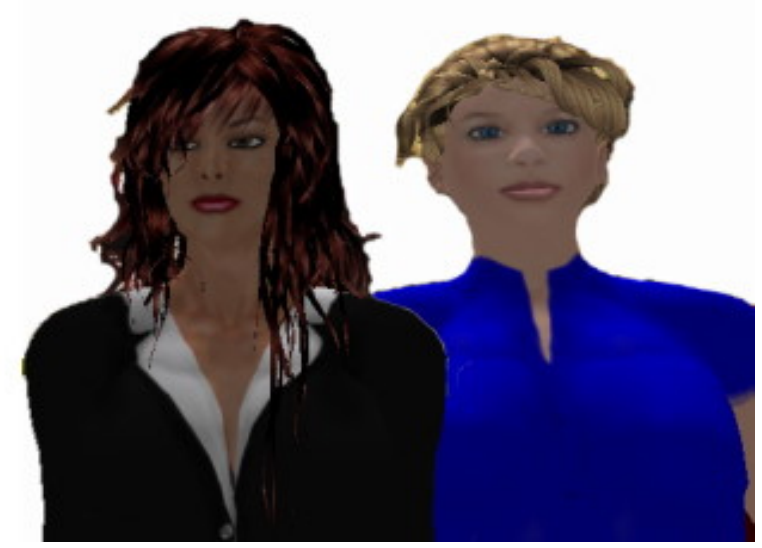

Figure 4: The authors' avatars - Jass Easterman (left) and Tamsyn Lexenstar (right)

\section{Data collection}

Different types of qualitative and quantitative data were collected in an attempt to assess the degree to which the real-life role-play was able to be replicated successfully in Second Life and the level of engagement experienced by students in each version of the activity.

Engagement in the context of this research was measured through observation, surveys and online dialogue recordings designed to target each of the three forms of engagement outlined earlier: affective, behavioural and cognitive. Affective engagement was assessed through all three modes - surveys, observation and online dialogue. It was hoped that the surveys and online dialogue would reveal what the students thought of the role-plays, and that we would additionally be able to observe students' real-life reactions to their role-plays (e.g. as expressed through their actual physical actions, body language and speech) that they may not have voiced through the survey or online text. Behavioural engagement was assessed through both the observation and the online dialogue. It was expected that these methods would tell us more about the students' engagement as evident in their physical behaviour during the role-playing activities than what was self-reported in the surveys. Cognitive engagement was assessed primarily through students' survey responses. In this case, we anticipated that the surveys would reveal what students thought and felt about the role-play, and the requirement that they be completed immediately after both the roleplays was intended to ensure that the perceptions and feelings captured were current.

The students were given a survey to complete at the end of each workshop to elicit their perceptions of the role-playing activity. Four questions were included in the survey that asked them to self-report, on a five-point scale: (i) the level of effort they 
invested into the activity; (ii) their level of interest in the activity; (iii) their level of engagement in the activity (how well it worked as a lesson); and (iv) the level of difficulty they faced. These questions enabled us to collect data about student engagement in the role-playing activity in terms of the affective, behavioural and cognitive aspects of their learning. A fifth question was also included that gave respondents the opportunity to write open-ended comments. A copy of the survey instrument containing actual questions asked of students about the role-playing activity is included in Appendix 1. This same survey was administered twice, once after the real-life workshop and again after the virtual world-based workshop. A second survey (reproduced in Appendix 2) was administered only upon conclusion of the virtual world workshop. That survey consisted of a mixture of 'Yes/No' and other multiple-choice items, as well as open-ended questions.

Students were observed during their participation in both the real-life and virtual world workshops by two academics, one an expert in teaching and learning and the other in teaching in a virtual world. All online dialogue was recorded for analysis. This enabled the gathering of data from several different angles. The academic observers verbally discussed their observations, thoughts and feelings after the workshops.

\section{Results and discussion}

\section{Quantitative results}

The quantitative survey responses suggest that the students found both the real-life and virtual world-based versions of the role-playing activity interesting and engaging. Table 2 shows the means and standard deviations of the responses to each of the rating-scale survey items for the real-life and virtual world versions. It also includes the difference between means in each case, paired t-test $(t)$, probability $(p)$ and effect size. The results show that the same amount of effort was put into the real-life workshops as the Second Life workshops, as perceived by the students.

Table 2: Student perceptions of the real-life and virtual-world versions of the role-playing activity

\begin{tabular}{|c|c|c|c|c|c|c|c|c|}
\hline \multirow[t]{2}{*}{ Survey question } & \multicolumn{2}{|c|}{$\begin{array}{l}\text { Real } \\
\text { life }\end{array}$} & \multicolumn{2}{|c|}{$\begin{array}{l}\text { Virtual } \\
\text { world }\end{array}$} & \multirow[t]{2}{*}{ Diff. } & \multirow[t]{2}{*}{$t$} & \multirow[t]{2}{*}{$p$} & \multirow{2}{*}{$\begin{array}{c}\text { Effect } \\
\text { size }\end{array}$} \\
\hline & $M$ & $S D$ & $M$ & $S D$ & & & & \\
\hline $\begin{array}{l}\text { Q1. How much effort did I put into my } \\
\text { learning? } \\
(1=\text { none; } 5=\text { as much as possible) }\end{array}$ & 3.83 & 0.74 & 3.77 & 0.83 & -0.06 & 0.6774 & .4009 & .076 \\
\hline $\begin{array}{l}\text { Q2. How interested was I in what I was } \\
\text { learning? }(1=\text { not interested at all; } \\
5=\text { really interested })\end{array}$ & 3.59 & 0.88 & 3.23 & 1.02 & -0.36 & 2.9613 & $.0039^{* *}$ & .378 \\
\hline $\begin{array}{l}\text { Q3. How engaged was I in what I was } \\
\text { learning? } \\
\text { ( } 1=\text { rarely engaged; } 5=\text { always engaged) }\end{array}$ & 3.77 & 0.90 & 3.43 & 1.11 & -0.34 & 2.5661 & $.0118^{*}$ & .336 \\
\hline $\begin{array}{l}\text { Q4. How difficult did I find the concept to } \\
\text { understand? } \\
\text { ( } 1=\text { extremely challenging; } 5=\text { very easy) }\end{array}$ & 3.49 & 0.78 & 3.21 & 0.83 & -0.28 & 2.7498 & $.0071^{* *}$ & .347 \\
\hline
\end{tabular}

However, the interest in what students were learning and how difficult they found the task were statistically highly significant and their engagement was statistically significant. The t-test results indicate that there was no statistical difference between 
the real-life and virtual world activities for question 1, and significant differences for the questions 2 to 4 . The mean differences, standard deviations and effect sizes were similar for questions 2 to 4 , hence it can be concluded that the increased ease of understanding correlates with interest and engagement. What ultimately matters with the analysis of matched data using a paired t-test is the consistency of the differences (Motulsky, 2002).

In relation to effect size, questions 2 to 4 yielded similar results. Responses to these questions showed medium to large effect size, which indicates that findings have practical importance (Cohen, 1992). Effect size is often used to measure students' improvement. These results strongly suggest that that the effect is not due to random chance, but that there is likely to be an underlying, repeatable cause as to why there is a discrepancy between the two workshops in terms of students' self-reported levels of interest and engagement in the activity as well as in terms of how difficult they perceived the task to be.

There was a high mean across all four of the rating-scale questions, indicating that the students were interested and engaged in both versions of the role-playing activity and found them challenging or difficult. The mean responses for the real-life versions of the activity were slightly higher; it is therefore clear that the students found carrying out the activity in real life more appealing and worthwhile than doing so in Second Life. At the same time, however, a point of interest is that the students found the real-life version of the activity more difficult than the virtual world version. This could possibly be interpreted an optimistic sign that role-playing activities in a virtual world can be a viable, effective alternative to real-life role-plays.

\section{Qualitative results}

The quantitative survey data presented above paint a largely positive picture of students' perceptions and attitudes in relation to both versions of the role-playing activity. The open-ended survey responses were, for the most part, reflective of this, with students claiming that they learnt a great deal about de Bono's Six Thinking Hats through the real-life version of the activity in particular. For example:

\footnotetext{
It was interesting to learn about the Six Hats as this was the first time I have encountered [this type of learning]

It was really good to allow us the chance to use the hats for ourselves because it gives us better opportunities when we teach it to the students
}

Enjoyed wearing the hat and changing roles. Really helpful and insightful

These students clearly understood the activity and its purpose, both from the point of view of using the Six Hats framework to enhance their own learning as well as in terms of exposing them to the framework in preparation for them to use it with their own students in the future. In relation to the virtual world-based version of the activity, students were using a virtual world for the first time, and initially found the experience surreal and difficult, according to the comments they wrote in the surveys. However, as the activity progressed they grew more accustomed to what, to them, was a new and novel way of interacting and communicating. With practice they became slightly more comfortable with, and more adept at, controlling their avatars to perform the tasks at hand, and as they did so began to see the educational potential of the technology: 
It was a good example of where technology is heading

I can see how it [a virtual world] could be a good tool, mostly for distance education...

[it] Took a bit to get used to, but with lessons I think it would be easy to catch on.

As with their qualitative feedback, many of the students' comments indicated that they preferred the traditional, real-life version of the role-playing activity. In fact, some students were quite negative in their comments about virtual worlds for education, with one stating:

I don't see myself using this [Second Life] in the future. I just don't like the fact a computer is teaching children rather than face-to-face

and another expressing the following concerns:

I don't think that it will work because the kids will focus more on the technological side of things. They will also get bored if they use it all the time.

Interestingly, the student who made the first comment above about Second Life was also dismissive of the Six Hats framework as a teaching tool, saying of it in the postreal-life-activity survey, "Personally, I have never seen it in a classroom and probably won't use it".

Other students gave more positive comments. For example, one remarked that the real-life role-playing activity was:

... confusing at the start but once we started I understood the concepts.

Another was able to articulate the benefits that arise from the anonymity it provides:

I have [sic] fun talking to everyone and not knowing who they were (sometimes when you know who it was [sic] you could be biased to what they have to say). I enjoyed myself. You should do this again.

It can be seen from the quotes given above that some of the students focused on the Six Thinking Hats framework (i.e. the pedagogical strategy) when commenting on the reallife version of the activity and on Second Life (the technology) when commenting on the virtual world-based version of the activity. However, as depicted in Table 3, there were several who were able to move beyond a mere focus on the technology including what would work and what would not from a purely technical or operational standpoint - to think deeply about the Six Thinking Hats framework and their experiences in the role-play scenarios. These students could see the value in both versions of the activity, as Table 3 illustrates, and although when reflecting on the reallife version of the activity the emphasis was on their own conceptual learning about the Six Hats framework, following the virtual world version this shifted to the practical possibilities of the framework and its application to the (primary) classroom.

It is also especially noteworthy that the comments made by many students in relation to the virtual world-based version of the activity were lengthier and more detailed in comparison to those they made about the real-life version of the activity, as the representative sample in Table 3 demonstrates. 
Table 3: Comparison of selected students' comments about the real-life and virtual world-based versions of the role-playing activity

\begin{tabular}{|l|l|}
\multicolumn{1}{|c|}{ Real life* } & \multicolumn{1}{|c|}{ Virtual world* } \\
\hline $\begin{array}{l}\text { I found it made a good way to think and } \\
\text { address issues regarding the topic }\end{array}$ & $\begin{array}{l}\text { Allows children to use computers in an } \\
\text { educational and social level. Was an interesting } \\
\text { way to learn about how technology is and is } \\
\text { going to impact on the classroom. }\end{array}$ \\
\hline $\begin{array}{l}\text { Good follow-on lesson from the lecture. Easier } \\
\text { to understand/remember. Handout is very } \\
\text { useful. }\end{array}$ & $\begin{array}{l}\text { I thought it was good. Once the hype slowed } \\
\text { down, we had some good points. It was } \\
\text { engaging and constant, meaning the interaction } \\
\text { levels were high. I liked it. I think it could work } \\
\text { well, so long as it was scaffolded effectively. } \\
\text { Students need to know the point of what they } \\
\text { are doing. }\end{array}$ \\
\hline $\begin{array}{l}\text { I find functional learning most effective. I } \\
\text { enjoyed it. }\end{array}$ & $\begin{array}{l}\text { There are pros and cons. It's always good to } \\
\text { experience new concepts/ technology to expand } \\
\text { one's knowledge base. I see how it } \\
\text { would / could be interesting to implement in the } \\
\text { classroom. There would be a place for this in } \\
\text { the classroom, but I don't think you would use } \\
\text { it all the time. Great for feeling 'included' as a } \\
\text { long distance student and for a teacher to } \\
\text { witness the contributions of an otherwise shy } \\
\text { student. Good fun. I found it frustrating at first, } \\
\text { but after I had the hang of it, was engaged... }\end{array}$ \\
\hline * The comments are from the same students in each case \\
\hline
\end{tabular}

Masters, a novice to teaching in Second Life, found that she improved in her ability to teach in the virtual world with each subsequent workshop. Her general perception was that each workshop was better than the preceding one, with the exception of the final workshop. This final workshop was conducted directly after the previous one, and Masters felt exhausted and not as perceptive to student needs during that workshop. These feelings were reflected in her beliefs about how well the workshop flowed and how the students responded to their activities in the virtual world. By comparing the lecturer's observations with the students' feedback a positive correlation can be seen with respect to perceptions of using virtual worlds as a teaching and learning tool by both students and lecturer. The lecturer felt the workshops "got better" as the week progressed and later workshops were the best, which was supported by students' survey data and online discourse. These views were also echoed by the two academic observers.

\section{Extending the activity to off-campus students}

As a result of the outcomes of the pilot study, the virtual world-based version of the Six Thinking Hats role-playing activity was offered to groups of off-campus Bachelor of Education (Primary) students in 2010 and 2011, with these students reporting extremely positive reactions. The activity provided these students with a unique and engaging learning experience that went a long way toward making up for their inability to partake in the activity in a real-life, on-campus situation, and did so in a rich and immersive way that could not have been accomplished through the standard tools provided by the University's LMS. One of the students from the 2010 off-campus cohort commented that: 
The opportunity to use Six Thinking Hats strategies in a group situation to guide discussion was deeply beneficial. It gave me a clearer understanding of how to use the hats, and provided an insight into how it may be used in a classroom (something that up until the Second Life session had eluded me). I am grateful for the opportunity to be able to participate in these tutorials, and value the experience highly.

A number of the on-campus students who participated in the pilot study pointed out a need for more and better scaffolding of the virtual world version of the activity. In response to this, in the second year of the pilot, students were given a chance to practise using Second Life beforehand during a dedicated tutorial session. A similar arrangement was adopted for the off-campus students, who attended an orientation and training session in Second Life a week prior to their role-play. In this way, the novelty of being in a virtual world was dissociated from the in-world role-playing activity, and students were able to concentrate on the activity itself rather than becoming caught up in the technical aspects of using the software.

Finally, some comments from off-campus students indicated that they found the virtual world activity so immersive that they 'forgot' they were involved in an (imaginary) role-play, as evidenced by comments like "I think I forgot about my hat". Another student found the role-play "... really interesting! It took a while to get going, but once I got into the swing, it was great". For one student, the degree of immersion was so great that he/she found it difficult to role-play one of the hats due to personal disagreement with the hat's 'personality':

Wearing the green hat was easy as I am a creative person, but then I tried the black hat and even though I could think of things to say, it was hard being so cautious about something I believe so passionately in!

\section{Conclusion and future research}

Overall, the study reported in this article has produced compelling evidence that realworld role-plays can be simulated or replicated in a virtual world, and its outcomes suggest that de Bono's Six Thinking Hats framework can be taught to off-campus students through engagement in such learning activities within a virtual world. These results add to the ever-growing corpus of research findings attesting to the efficacy of virtual worlds for learning and teaching in a virtual world. The results of the pilot study suggest that students have a preference for real-life, face-to-face learning activities; however, the participants in the study were on-campus students, who, unlike those who are studying at a distance, actually have the privilege of access to this mode of learning. Nevertheless, for off-campus students, a virtual world-based roleplay may be a viable substitute for real-life role-plays, although further research is required to better understand these students' perceptions, preferences and experiences. To this end, data collection is already underway with the off-campus students at UNE to whom the Six Thinking Hats activity has been extended. More work is also needed to ascertain whether and how best virtual worlds can be used to add value to the oncampus student learning experience, through its unique characteristics (e.g. the ability to provide anonymity in a role-play situation) and by making possible experiential tasks and activities that would otherwise be impossible for students to undertake in the real world.

In the future, we intend to undertake a comparison of on- and off-campus students' perceptions of the virtual world-based role-playing activity, and to try including a 
mixture of on- and off-campus students in 'blended synchronous' (Bower, Kennedy, Dalgarno \& Lee, 2011) role-plays that would see students studying in both modes interacting and collaborating with one another in real time. We also plan to expand the scope of the study to involve examination of other types of role-playing activity relevant to teacher education (e.g. teacher/student role-plays). Additionally, there are a number of methodological limitations of the present study that could be alleviated or overcome in future research. For example, future studies could provide the higher education sector with evidence that role-play in a virtual world is an effective learning and teaching strategy for both on- and off-campus student in terms of the actual learning benefits and outcomes achieved by students as a result of their participation in such activities, rather than simply in terms of their perceived learning. Detailed, systematic analysis of the observation notes and chat transcripts from the pilot study will go some way towards addressing this. Another shortcoming of the present study is that given that the same students in the pilot study first undertook the real-life version of the role-playing activity and then later undertook the virtual world-based version of the activity, the results may have been influenced by order effects. These effects may be dealt with by varying the experimental design so that half of the students undertake the virtual world version before the real-life version.

\section{Acknowledgments}

The authors would like to acknowledge the contributions of the following: the members of UNE School of Education Writing for Publications Group, who provided feedback on the article; Dr Stefan Horarik, Dr Chris Reading and Dr Mitchell Parkes, for their assistance in analysing the data; and the UNE School of Education Research Initiative Grant, which supplied funding that enabled this project to come to fruition.

\section{References}

Andreasen, J. B. \& Haciomeroglu, E. S. (2009). Teacher training in virtual environments. In S. L. Swars, D. W. Stinson \& S. Lemons-Smith (Eds), Embracing diverse perspectives. Proceedings of the 31st Annual Meeting of the North American Chapter of the International Group for the Psychology of Mathematics Education (pp. 1317-1324). Atlanta, GA: Georgia State University. http: / / www.pmena.org/2009/ proceedings/scrollingbook9_15.pdf

Backe, M. (2011). Make-believe and make-belief in Second Life role-playing communities. Convergence, 18(1), 85-92. http: / / dx.doi.org/10.1177/1354856511419917

Beach, R. \& Doerr-Stevens, C. (2009). Learning argument practices through online role-play: Toward a rhetoric of significance and transformation. Journal of Adolescent $\mathcal{E}$ Adult Literacy, 52(6), 460-468. http: / / dx.doi.org/10.1598/JAAL.52.6.1

Bower, M., Kennedy, G. E., Dalgarno, B. \& Lee, M. J. W. (2011). Uniting on-campus and distributed learners through media-rich synchronous tools: A national project. In Changing demands, changing directions. Proceedings ascilite Hobart 2011 (pp. 150-155). Hobart: University of Tasmania.

http: / / www.ascilite.org.au/conferences/hobart11/ downloads/ papers / Bower-concise.pdf

Cohen, J. (1992). A power primer. Psychological Bulletin, 112(1), 155-159. http: / / dx.doi.org/10.1037/ 0033-2909.112.1.155

Dalgarno, B., Lee, M. J. W., Carlson, L., Gregory, S. \& Tynan, B. (2011). An Australian and New Zealand scoping study on the use of 3D immersive virtual worlds in higher education. Australasian Journal of Educational Technology, 27(1), 1-15. http:/ / www.ascilite.org.au/ajet/ajet27/ dalgarno.html 
De Bono, E. (1985). Six Thinking Hats. London: Penguin.

Gao, V., Noh, J. \& Koehler, M. (2008). Comparing student interactions in Second Life and face-toface role-playing activities. In K. McFerrin, R. Weber, R. Carlsen \& D. A. Willis (Ed.), Proceedings of Society for Information Technology and Teacher Education International Conference (pp. 2033-2035). Chesapeake: VA: Association for the Advancement of Computers in Education. http:/ / www.editlib.org/p/27499

Greene, B. A. \& Miller, R. B. (1996). Influences on achievement: Goals, perceived ability, and cognitive engagement. Contemporary Educational Psychology, 21(2), 181-192. http: / / dx.doi.org/10.1006/ ceps.1996.0015

Green-Hamann, S., Eichorn, K. C. \& Sherblom, J. C. (2011). An exploration of why people participate in Second Life social support groups. Journal of Computer-Mediated Communication, 16(4), 465-491. http: / / dx.doi.org/10.1111/j.1083-6101.2011.01543.x

Gregory, B. (2009). Business uses of a virtual world. [viewed 9 Jun 2009] http: / / www.virtualclassrooms.info/slbusiness.htm

Gregory, B., Gregory, S., Wood, D., Masters, Y., Hillier, M., Stokes-Thompson, F., ...Yusupova, A. (2011). How are Australian higher education institutions contributing to change through innovative teaching and learning in virtual worlds? In Changing demands, changing directions. Proceedings ascilite Hobart 2011 (pp. 475-590). Hobart: University of Tasmania. http:/ / www.ascilite.org.au/conferences / hobart11/ downloads/ papers/Gregory-full.pdf

Gregory, S. (2011). Learning in a virtual world: Student perceptions and outcomes. In K. Moyle \& G. Winjnaards (Eds), Student reactions to learning with technologies: Perceptions and outcomes (pp. 91-116). Hershey, PA: Information Science Reference. http:// dx.doi.org/10.4018/978-161350-177-1.ch005

Gregory, S., Dalgarno, B., Campbell, M., Reiners, T., Knox, V. \& Masters, Y. (2011). Changing directions through VirtualPREX: Engaging pre-service teachers in virtual professional experience. In Changing demands, changing directions. Proceedings ascilite Hobart 2011 (pp. 491501). Hobart: University of Tasmania.

http: / / www.ascilite.org.au/conferences/ hobart11/downloads / papers / GregoryS-full.pdf

Gregory, S., Lee, M. J. W., Ellis, A., Gregory, B., Wood, D., Hillier, M., ... McKeown, L. (2010). Australian higher education institutions transforming the future of teaching and learning through 3D virtual worlds. In Curriculum, technology $\mathcal{E}$ transformation for an unknown future. Proceedings ascilite Sydney 2010 (pp. 399-415). Brisbane: The University of Queensland. http: / / www.ascilite.org.au/conferences / sydney 10 / Ascilite $\% 20$ conference $\% 20$ proceedings $\% 202010 /$ Gregory-full.pdf

Gregory, S. \& Masters, Y. (2010). Six hats in Second Life: Enhancing preservice teacher learning in a virtual world. Paper presented at the International Conference on Teaching and Learning with Technology, Singapore, 2-6 March. [viewed 12 Mar 2012]

http: / / www.virtualclassrooms.info/ papers / Six\%20Hats\%20in\%20Second\%20Life.pdf

Gregory, S. \& Smith, H. (2010). How virtual classrooms are changing the face of education: Using virtual classrooms in today's university environment. In W. Halloway \& J. Maurer (Eds), International research in teacher education: Current perspectives (pp. 239-252). Armidale, Australia: University of New England.

Gregory, S. \& Tynan, B. (2009). Introducing Jass Easterman: My Second Life learning space. In Same places, different spaces. Proceedings ascilite Auckland 2009 (pp. 377-386). Auckland: The University of Auckland and Auckland University of Technology.

http: / / www.ascilite.org.au/conferences/auckland09/procs/gregory.pdf 
Hu, S. \& Kuht, G. D. (2002). Being (dis)engaged in educationally purposeful activities: The influences of student and institutional characteristics. Research in Higher Education, 43(5), 555575. http:/ / dx.doi.org/10.1023/ A:1020114231387

Inman, C., Wright, V. H. \& Hartman, J. A. (2010). Use of Second Life in K-12 and higher education: A review of research. Journal of Interactive Online Learning, 9(1), 44-63. http: / / www.ncolr.org/jiol/ issues/getfile.cfm?volID=9\&IssueID=28\&ArticleID=143

Jimerson, S. R., Campos, E. \& Greif, J. L. (2003). Toward an understanding of definitions and measures of school engagement and related terms. The California School Psychologist, 8, 7-27. http: / / www.education.ucsb.edu/ school-psychology/CSP-

Journal/PDF/CSP2003(volume_8).pdf

Kemmis, S. \& McTaggart, R. (Eds) (1988). The action research planner (3rd ed.). Melbourne: Deakin University.

Krause, K.-L. (2005). Understanding and promoting student engagement in university learning communities. Melbourne: Centre for the Study of Higher Education, The University of Melbourne.[viewed 11 Mar 2011]

http:/ / www.cshe.unimelb.edu.au/resources_teach/teaching_in_practice/docs/Stud_eng.pdf

Lee, M. J. W., Dalgarno, B., Gregory, S., Carlson, L. \& Tynan, B. (2011). How are Australian and New Zealand higher educators using $3 D$ immersive virtual worlds in their teaching? Paper presented at the DEHub and ODLAA Education Summit 2011-2021, Sydney, Feb 15-18.

Lee, M. J. W., Eustace, K., Fellows, G., Bytheway, A. \& Irving, L. (2005). Rochester Castle MMORPG: Instructional gaming and collaborative learning at a Western Australian school. Australasian Journal of Educational Technology, 21(4), 446-469. http:/ / www.ascilite.org.au/ajet/ajet21/lee.html

Linden Research (2009). Second Life statistics. [viewed 15 Nov 2009] http: / / www.secondlife.com/whatis/economy_stats.php

Liu, M., Kalk, D., Kinney, L. \& Orr, G. (2012). Web 2.0 and its use in higher education from 20072009: A review of literature. International Journal on E-Learning, 11(2), 153-179. http: / / www.editlib.org/p/34087

Masters, Y. \& Gregory, S. (2011). Second Life: A novice/ expert teaching and learning tale. Paper presented at the DEHub and ODLAA Education Summit 2011-2021, Sydney, Feb 15-18.

Mayrath, M., Sanchez, J., Traphagan, T., Heikes, J. \& Trivedi, A. (2007). Using Second Life in an English course: Designing class activities to address learning objectives. In C. Montgomerie \& J. Seale (Eds), Proceedings of World Conference on Educational Multimedia, Hypermedia and Telecommunications 2007 (pp. 4219-4224). Chesapeake, VA: Association for the Advancement of Computers in Education. http:/ / www.editlib.org/p/25985

Motulsky, H. (2002). The link between error bars and statistical significance. [viewed 7 Mar 2012] http:/ / www.graphpad.com/articles/errorbars.htm

Phillips, J. M. (2005). Chat role play as an online learning strategy. Journal of Nursing Education, $44(1), 43$.

Rappa, N. A., Yip, D. K. H. \& Baey, S. C. (2009). The role of teacher, student and ICT in enhancing student engagement in multiuser virtual environments. British Journal of Educational Technology, 40(1), 61-69. http:/ / dx.doi.org/10.1111/j.1467-8535.2007.00798.x

Reaburn, P., Muldoon, N. \& Bookallil, C. (2009). Blended spaces, work based learning and constructive alignment: Impacts on student engagement. In Same places, different spaces. Proceedings ascilite Auckland 2009 (pp. 820-831). Auckland: The University of Auckland and 
Auckland University of Technology.

http: / / www.ascilite.org.au/conferences / auckland09/ procs/reaburn.pdf

Reading, C. (2008). Recognising and measuring engagement in ICT-rich learning environments. Paper presented at the 2008 Australian Computers in Education Conference, Canberra, 29 Sep-2 Oct. http: / / www.acce.edu.au/ sites / acce.edu.au / files / archived_papers / conf_P_926_ engagement.pdf

Roeser, R. W., Strobel, K. R. \& Quihuis, G. (2002). Studying early adolescents' academic motivation, social-emotional functioning, and engagement in learning: Variable- and personcentered approaches. Anxiety, Stress \& Coping, 15(4), 345-368. http: / / dx.doi.org/10.1080/1061580021000056519

Russell, V. J., Ainley, M. \& Frydenberg, E. (2005). Schooling Issues Digest: Student motivation and engagement. Canberra: Department of Education, Employment and Workplace Relations. [viewed 9 Mar 2009] http:/ / www.dest.gov.au/sectors/school_education/publications_ resources/schooling_issues_digest/schooling_issues_digest_motivation_engagement.htm

Schaufeli, W., Bakker, A. \& Salanova, M. (2006). The measurement of work engagement with a short questionnaire: A cross-national study. Educational and Psychological Measurement, 66(4), 701-716. http: / / dx.doi.org/10.1177/ 0013164405282471

Slator, B. M. \& Chaput, H. (1996). Learning by learning roles: A virtual role-playing environment for tutoring. In C. Frasson, G. Gauthier \& A. Lesgold (Eds), Proceedings of the Third International Conference on Intelligent Tutoring Systems. Vol. 1086 Lecture Notes in Computer Science (pp. 668-676). Berlin: Springer-Verlag. http: / / dx.doi.org/10.1007/3-540-61327-7_167

University of New England (2011). UNE overview: Facts \& figures. [viewed 10 Mar 2012] http:// planning.une.edu.au/Statistics/overview /

\section{Appendix 1: Student survey on the Six Thinking Hats role-playing activity}

The following survey was administered twice, once after the face-to-face role-playing activity and again after the virtual world-based version of the activity.

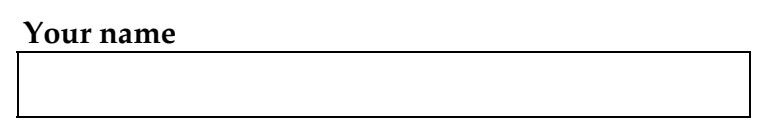

Avatar name

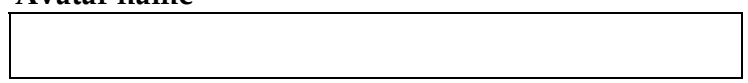

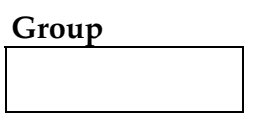

Your gender

Male $\square \quad$ Female $\square$

Please answer the following questions in relation to the Edward de Bono's Six Hats activity. (Tick the relevant boxes)

1. How much effort did I put into my learning?

\begin{tabular}{|c|c|c|c|c|}
\hline $\begin{array}{c}1 \\
\text { I didn't put in any } \\
\text { effort }\end{array}$ & $\begin{array}{c}2 \\
\text { I didn't put in } \\
\text { very much effort }\end{array}$ & $\begin{array}{c}\text { I put in some } \\
\text { effort }\end{array}$ & $\begin{array}{c}4 \\
\text { I put in lots of } \\
\text { effort }\end{array}$ & $\begin{array}{c}5 \\
\text { I put in as much } \\
\text { effort as I could }\end{array}$ \\
\hline
\end{tabular}

2. How interested was I in what I was learning?

\begin{tabular}{|c|c|c|c|c|}
\hline $\begin{array}{c}\text { I was not } \\
\text { interested at all }\end{array}$ & $\begin{array}{c}\text { I was a bit } \\
\text { interested }\end{array}$ & $\begin{array}{c}3 \\
\text { I was interested }\end{array}$ & $\begin{array}{c}4 \\
\text { I was very } \\
\text { interested }\end{array}$ & $\begin{array}{c}\text { I was really } \\
\text { interested }\end{array}$ \\
\hline
\end{tabular}


3. How engaged was I in what I was learning (i.e. did it work as a lesson)?

\begin{tabular}{|c|c|c|c|c|}
\hline $\begin{array}{c}1 \\
\text { I was rarely } \\
\text { engaged }\end{array}$ & $\begin{array}{c}2 \\
\text { I was occasionally } \\
\text { engaged }\end{array}$ & $\begin{array}{c}3 \\
\text { I was engaged }\end{array}$ & $\begin{array}{c}4 \\
\text { I was mostly } \\
\text { engaged }\end{array}$ & $\begin{array}{c}\text { I was always } \\
\text { engaged }\end{array}$ \\
\hline
\end{tabular}

4. How difficult did I find the concept to understand?

\begin{tabular}{|c|c|c|c|c|}
\hline $\begin{array}{c}\text { Extremely } \\
\text { challenging }\end{array}$ & Challenging & Not too bad & $\begin{array}{c}3 \\
\text { Easy }\end{array}$ & $\begin{array}{c}5 \\
\text { Very easy }\end{array}$ \\
\hline
\end{tabular}

5. Please write a short statement about your general impressions of using de Bono's Six Thinking Hats.

\section{Appendix 2: Student survey on the Second Life experience}

The following survey was administered after the virtual world-based version of the activity only.

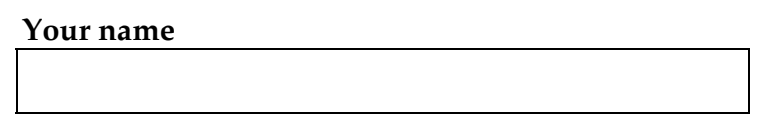

Avatar name

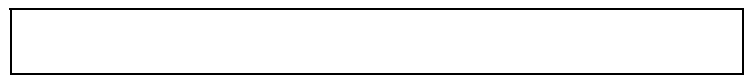

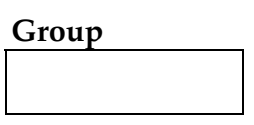

Your gender

Male $\square \quad$ Female $\square$

Please answer the following questions in relation to your experience using Second Life.

1. How would you rate your skill level with ICT in general?

Very high $\square \quad$ High $\square \quad$ Average $\square \quad$ Low $\square \quad$ Very low $\square$

2. Have you used Second Life before (other than sessions for [unit name])?

Yes $\square \quad$ No $\square$

3. Have you used Second Life for educational purposes before?

Yes $\square \quad$ No $\square$

4. Have you attended any Second Life classes before (other than for [unit name])?

Daily $\square \quad$ Twice a week $\square \quad$ Weekly $\square \quad$ Less than weekly $\square \quad$ Never $\square$

5. Did you enjoy using Second Life as an educational tool?

Yes $\square \quad$ No $\square$

Please briefly expand on your answer. 
6. Please write a short statement about your general impressions of using Second Life as an educational tool.

\section{Authors: Sue Gregory, Lecturer in ICT Education}

School of Education, University of New England, Armidale, NSW 2351, Australia Email: sue.gregory@une.edu.au Website: http: / /www.virtualclassrooms.info/

Sue is responsible for training pre-service and postgraduate education students on how to incorporate technology into their teaching. Since 2008, through her avatar, Jass Easterman, she has taught over 500 students in Second Life, and over this period has performed extensive research into the pedagogical opportunities that virtual worlds provide and their efficacy as a tool for learning. Sue is the Chair of the Australian and New Zealand Virtual Worlds Working Group and is currently leading a project titled "VirtualPREX: Innovative assessment using a 3D virtual world with pre-service teachers", which has received funding through an Australian Learning and Teaching Council (ALTC) Priority Grant.

Dr Yvonne Masters, Lecturer in Teaching and Learning and Director of Professional Experience, School of Education, University of New England Armidale, NSW 2351, Australia. Email: ymasters@une.edu.au

Yvonne has responsibility for overseeing all professional experience (practicum) requirements in the teaching courses at UNE. She began using virtual worlds in her teaching in 2009, and since that time has been a member of the Australian and New Zealand Virtual Worlds Working Group led by Sue. She is also working with Sue on the VirtualPREX project. Yvonne's alter ego in Second Life is Tamsyn Lexenstar.

Please cite as: Gregory, S. \& Masters, Y. (2012). Real thinking with virtual hats: A roleplaying activity for pre-service teachers in Second Life. In M. J. W. Lee, B. Dalgarno \& H. Farley (Eds), Virtual worlds in tertiary education: An Australasian perspective. Australasian Journal of Educational Technology, 28(Special issue, 3), 420-440. http: / / www.ascilite.org.au/ajet/ajet28/gregory.html 